\title{
The Influence of the Model Problem Based Instruction On Mathematical Problem- Solving Skills of Students On the Material Perform the Operation Form of Algebra
}

\section{Rina Oktaviyanthi}

Universitas Serang Raya, Jl. Raya Serang - Cilegon Km. 5, Taman Drangong, Serang,

Email: rinaocta@unsera.ac.id

\begin{abstract}
perform the operation form of the algebra. The purpose of this study is to determine whether the ability of mathematical problem solving of students who obtained learning using the model of Problem Based Instruction is better than on mathematics problem solving ability of students who obtained learning using the conventional method of learning and how students ' attitudes towards learning mathematics using the model of Problem Based Instruction. The instruments used are : (1) Test the ability of early mathematics, (2) Test the ability of mathematical problem solving, (3) the response of students, (4) the observation Sheet. The instrument has met the terms validity and reliability coefficient of $r \_x y=0,86$ and $t \_h i t u n g=$ 9,383 . This type of research is quasi-experiment. Sample experiment 32 students, a control sample of 32 students random sampling. The object of research: problem-solving abilities. The research Data the initial test, final test and questionnaire of students ' attitudes.Of the research problem solving obtained $F_{-}$(count $)=8,79>F_{-}($table $)=4,15$ there are differences in the improvement of mathematics problem solving ability of students who are given the PBI compared with students who were given the PMK. Conclusion : There is the influence of problem-solving ability of mathematics students who received problem-based learning model (Problem Based Intruction) is better than the mathematics problem solving ability of students who obtain a model of conventional teaching.
\end{abstract}

\section{Keywords: Ability Pembekahan Problem, Problem based instruction( PBI)}

\section{INTRODUCTION}

Learning the less involve students actively in learning, it can inhibit the ability of students studying mathematics in the solution of the problem, so it needs to be selected and applied a learning model to realize the achievement of learning objectives. The Education Unit Level curriculum (KTSP) requires the learning situation that is natural, that students learn in earnest with a way to experience and find their own learning experience. When students learn mathematics, then that is studied is the application of mathematics to the students. Learning situations should be able to present real-world phenomena, the problem of authentic and meaningful that can challenge the students to solve it. One of the models in accordance with the matters described above is a learning based on the problem or Problem Based Instruction (PBI). According to the Nurhadi (in the Prasetyo, 2011: 12), Problem Based Instruction is a learning model that uses real-world problems as a context to learn about critical thinking and problem solving skills, and acquire knowledge and concepts that 
are essential from the subjects. As for the characteristics of problem-based learning (PBI) is to orient the students on the problems of the authentic, a concentration of inter-disciplinary knowledge, the investigation of authentic, cooperation, to produce the work (Ibrahim in the Prasetyo, 2011: 4). This Model of learning based on the development of thinking skills among students through exercises problem solving, and therefore the students involved in the process and the acquisition of product completion. Thus, this model will also develop thinking skills through the empirical facts and the ability to think rationally, so repeated practice can develop intellectual skills and at the same time can mature students. Learning math will be meaningful for students, if learning is done in accordance with the initial knowledge of the students. From the initial knowledge, the teacher gives the material/learning resources in accordance with the basic competencies desired, further conditioned by the guidance of the teacher so that the students are active in constructing their own knowledge. Learning will be meaningful if the teacher relate the new knowledge with the experience which has been owned by the students.

Related to the above description, the researcher will conduct research with the title: "the Influence of the Model Problem Based Instruction On Mathematical Problem-Solving Skills of Students On the Material Perform the Operation On the Shape of Algebra.

\section{RESEARCH METHODS}

Model PBI or learning based on the problem has been known since the time of John Dewey, because in general learning based on problem consists of presenting to the students the problem situation that is authentic and meaningful that can provide convenience to them to do an investigation and inquiry.

Learning by problem (hereinafter abbreviated as PBI) is based on the theory of cognitive psychology. The focus of teaching is not so much on what is being done students (their behavior), but rather to what they think (cognition them) when they do the activity. Although the role of the teacher in learning this sometimes involves the presentation and explanation of a thing, but more prevalent is role as mentors and facilitators so that students learn to think and solve problems.

According to the Nurhadi (in the Prasetyo, 2011: 12), Problem Based Instruction is a learning model that uses real-world problems as a context to learn about critical thinking and problem solving skills, and acquire knowledge and concepts that are essential from the subjects.

According to Arends (in the Prasetyo, 2011: 13) mentions that the PBI or teaching based on problem is a learning model where students work on the problems that are authentic, with the intent to compose their own knowledge, develop inquiry skills and highlevel thinking, develop self-reliance and self-confident.

Thus, the teaching of problem based approach is effective in helping students to process the information already there in her mind and compose their own knowledge about the social world. In the acquisition of information and the development of an understanding of the topics, students learn how to construct the framework of the issue, organize and investigate the problem, collect and analyze data, compile the facts, construct arguments about problem solving, working individually or in collaboration in problem solving. 


\section{Stages Problem Based Instruction Model}

\begin{tabular}{|c|c|}
\hline Tahap & Kegiatan guru \\
\hline $\begin{array}{l}\text { Stage }-1 \\
\text { The orientation of students to } \\
\text { the problem }\end{array}$ & $\begin{array}{l}\text { The teacher explains the learning objectives } \\
\text { and describes the logistics required, as well as } \\
\text { motivate students to engage in problem-solving } \\
\text { theory. }\end{array}$ \\
\hline $\begin{array}{l}\text { Stage }-2 \\
\text { Organize students to learn }\end{array}$ & $\begin{array}{l}\text { Teachers help students define and organize the } \\
\text { learning activities associated with the problem. }\end{array}$ \\
\hline $\begin{array}{l}\text { Stage }-3 \\
\text { Guiding the investigation } \\
\text { Individually or in groups }\end{array}$ & $\begin{array}{l}\text { Teachers encourage students to gather the } \\
\text { appropriate information, carry ou } \\
\text { observation/experiment to get an explanation } \\
\text { and problem solving. }\end{array}$ \\
\hline $\begin{array}{l}\text { Stage }-4 \\
\text { Develop and } \\
\text { Presents the results of works }\end{array}$ & $\begin{array}{l}\text { Teachers help students plan and prepare work } \\
\text { tools such as reports, posters, poems and model } \\
\text { that help them to share tasks with friends. }\end{array}$ \\
\hline $\begin{array}{l}\text { Stage }-5 \\
\text { Analyze and evaluate } \\
\text { The process of solving the } \\
\text { problem }\end{array}$ & $\begin{array}{l}\text { Teachers help students to do reflection of } \\
\text { evaluation of their investigation and the } \\
\text { processes that they use. }\end{array}$ \\
\hline
\end{tabular}

\section{Type Of Research}

\section{RESULTS AND DISCUSSION}

There are two types of research, namely quantitative research and qualitative research. According to Malau (in Fahmi, 2012:80) quantitative research refers to the notion that a social phenomenon can be measured and converted in the form of numbers, so that it can be performed statistical calculations to analyze the data both for the purposes of descriptive and to test the hypothesis, and make a conclusion. Meanwhile, according to the Bogman and Taylor (in Fahmi, 2012:80) qualitative research is as a research procedure that produces descriptive data in the form of words written or spoken of the people and observed behavior, according to them we should not isolate individual or organization into a variable or a hypothesis, but needs to be looked at as part of wholeness.

This study uses a quantitative research approach with experimental methods in the form of quasi-experimental. Experimental research according to Ruseffendi (2005:35) is the research really to see cause-effect relationships. The treatment that we have done to the independent variable we see the results on the dependent variable. This research aims to study about problem-solving ability and students ' attitudes are influenced by the model of learning that is Problem Based Instruction (PBI) and conventional learning. 


\section{Data Collection Techniques}

The technique of data collection tests the ability of students 'problem-solving, sheet students' attitudes, and the observation sheet activities of teachers and students towards the learning activities. All data will be dinalisis for the withdrawal of the conclusion.

1. The value of the test results of the students 'problem solving abilities after answering the questions given by the teachers at the end of each cycle consisting of 5 about the description in each cycle that serves to determine the ability of students' problemsolving.

2. Result sheet of students ' attitudes toward learning, Problem Based Intruction (PBI) given by the teachers towards the students which consists of 25 questions by giving a check mark $(\sqrt{ })$ in the column provided for each statement given.

3. The results of the observation of the activities of teachers and students on learning takes place. Observation sheet using a table of guidelines for observation to determine the level of teacher activity and student activity during the learning takes place by providing the 17 questions and each question is given the sign of the cross in the appropriate column.

4.

Research Data

The analyzed Data is the result obtained from the results of LKS has been tailored to each score of each indicator of learning.

a. Test Problem Solving Skills

Test conducted the essay form as much as 5 questions that were implemented at the end of each study, the results of this test will be used to determine the increase in the ability of students ' problem-solving through problem based Intruction (PBI). The score of students ' problem solving Abilities obtained from the results of the scores obtained is divided by the maximum score is multiplied by 100 , is formulated as follows:

The description of the category scores of students ' problem solving abilities refer to the scale of Grounlund (1982;33) is as follows.

$\mathrm{SKB} \geq \mathrm{M}+2 \mathrm{SD}:$ means "Very good"

$\mathrm{M}+\mathrm{SD} \leq \mathrm{LCS}<\mathrm{M}+2 \mathrm{SD}:$ means "Good"

$\mathrm{M}-1 \mathrm{SD} \leq \mathrm{LCS}<\mathrm{M}+\mathrm{SD}:$ mean "Good Enough"

$\mathrm{M}-2 \mathrm{SD} \leq \mathrm{LCS}<\mathrm{M}-1 \mathrm{SD}$ : means "Less is Better"

LCS $<$ M - 2SD : means "Not Good"

Description: $\mathrm{SKB}=$ Score Learning Ability

$\mathrm{M}=$ Mean

$\mathrm{SD}=$ Standard Deviation

Individually, students are said to have been able to solve the problem if the Score is problem solving Skills acquired at least reach the category of "good enough". Furthermore, a group is said to have been capable of learning (the ability of the classical style) if there are at least $80 \%$ of students have a Score of problem-solving Ability with a minimum achieve the good enough category.

b. Questionnaire Of Students ' Attitudes

Questionnaire of students ' attitudes toward learning, Problem Based Intruction (PBI) were analyzed with the following steps :

1. Create a summary of the results of the questionnaire the end of the students.

2. Calculate the percentage of students ' answers. 
3. Perform data analysis of the questionnaire and a self-evaluation by comparing the interests, skills, level of understanding, and the attitude of students in learning. A positive statement has a score of 5 for the category of strongly agree (SS), a score of 4 for agree (S), 3 scores for the undecided (RR), a score of 2 for disagree (TS), and a score of 1 to strongly disagree (STS). Then the statement is negative also has a score of 5 for the categories of strongly disagree (STS), a score of 4 to disagree (TS), 3 scores for the undecided (RR), a score of 2 to agree (S), and a score of 1 to strongly agree (SS).

4. Analysis of the data presented in descriptive form.

c. Analysis of the results of observation of the teacher's activities and student activities

The activities of the teacher, is calculated by using the formula Perentase Average Score (RS) :

$$
R S=\frac{\text { total score }}{\text { Maximum score }} \times 100 \%
$$

The maximum score for the observation of the teacher's activities : $17 \times 5=85$

The maximum score for the observation of the activities of students : $17 \times 5=85$

Where : $90 \% \leq \mathrm{RS}<100 \%$ : means "Very good"

$80 \% \leq \mathrm{RS}<90 \%$ : means "Good"

$70 \% \leq \mathrm{RS}<80 \%$ : means "Good Enough"

$60 \% \leq \mathrm{RS}<70 \%$ : means "Less is Better"

$0 \% \leq \mathrm{RS}<60 \%$ : means "Not Good

After all necessary data has been collected, proceed with the processing of such data as the material to answer the problems that exist in the research. As for the procedure for data processing is as follows :

1. Analysis of data from the initial test (pretest) :

a. Calculate the value of the mean of experimental class and control class.

b. Calculate the standard deviation of the experimental class and the control class

c. Normality test to both classes

d. If not normal, then the test is conducted non-parametric statistics with the use of the test, Mann-Whitney U-Test.

e. Perform a test of the homogeneity of the two variances.

f. Do test the similarity of two average by using t-test, but if it is not homogeneous proceed with the test $t$ '.

2. Data analysis the final test (posttest) :

a. Calculate the value of the mean of experimental class and control class

b. Calculate the standard deviation of the experimental class and the control class

c. Normality test to both classes

d. If not normal, then the test is conducted non-parametric statistics with the use of the test, Mann-Whitney U-Test.

e. Perform a test of the homogeneity of the two variances.

Do test the similarity of two average by using t-test, but if it is not homogeneous proceed with the test $\mathrm{t}$.

\section{The Ability Of Mathematical Problem Solving}

As has been stated before, that what is meant by problem-solving ability is the ability of students to understand the problem, plan the troubleshooting, perform calculations and checking back. The results of the research show, the achievement of outcomes problem 
solving ability and students with problem-based learning is much larger than the class that is subject to direct teaching. Mastery learning is achieved in a class experiment, i.e. there are 28 people from 32 students or of $87.5 \%$ of the number of students in the experimental class who thoroughly studied based on the criteria of mastery learning curriculum. While in the control class there are 18 students or $56,25 \%$.

Problem-based learning Model significantly has managed to increase the problem solving ability of mathematics students when compared with direct teaching. The results of research from the constants of the regression equation for the problem-based learning, namely 29,69 while the direct teaching 24,56.

Reviewed aspects of understanding the problems there are in all the numbers about, for problem-based learning only 20 students from 32 students can answer questions correctly while in the direct teaching there are 10 students. The number of students who are able to understand the problem in problem-based learning more than the direct teaching because on one of the characteristics of problem-based learning is the filing of a contextual problem so as to make students able to think critically. The same thing also raised by Nurhadi (2003: 109). While in direct teaching, the students just follow the completion of which has been created teacher. The difficulties of the students do not know the data or not enough to resolve the matter. From the results of the interview, they just guess.

In the aspect of plan completion, to problem-based learning there are 22 students write down a mathematical model or memisalkannya with a particular variable in a complete whereas in the direct teaching there are 17 students. In class-based problems described what is the meaning of the variable $\mathrm{x}$. As for the steps of making the correct plan to the questions of problem solving, namely, the first by making pemisalan of what is known in the form of two variables. Next create the equation of mathematics in the form of the equation. Then make planning to resolve the problem, namely finding the value of the variable which is assumed earlier. In-class direct teaching most students directly resolve the matter without writing model matematikannya. So that the average student answers a group of problem-based learning has a better answer and sensible when compared with the group of direct teaching. The aspect of doing the calculation, there are several questions to be done students with complete, there are also wrong in doing calculations (addition and division). To seek a resolution of the problem (answers) the students should be able to utilize their knowledge. Completion of the end (the answer) is not the final goal of learning math, but rather as the largest part of this activity (Turmudi, 2008). From this study the number of students who wrote the troubleshooting is complete and correct on problem-based learning as many as 25 students while in the direct teaching there are 16 students. Variation answers in the test class more compared with the control group.

Aspect checking back, on problem-based learning, there are 18 students who were able to write it, most students simply write "Correct", while in the direct teaching there are 10 students. In-class problem-based variety of students in a re-examine the answers obtained diverse while in class direct teaching only a fraction of students who are capable. Students are not able to check back on the results obtained, reviewed the process of settlement has been made. According to the TEAM MKPBM (2001) that: think of or look at the steps that have been done in solving the problem is a very important activity to increase the students ' ability in problem solving.

\section{CONCLUSION}


Based on the results of data analysis and research findings during problem-based learning with an emphasis on problem-solving ability, the researchers obtained the following conclusion:

1. From the results of calculation $F=8,79$ and $F=4,15$. Mean F F . H is rejected and accepted $\mathrm{H}$. It means that there is a positive influence (significance) mathematics problem solving ability of students who obtain a model of problem-based learning (Problem Based Intruction) is better than the problem solving ability of mathematics students who earn a teaching model conventional, obtained the average problem solving ability of mathematics students who received problem-based learning model (Problem Based Intruction) is 6,94 while the average mathematics problem solving ability of students who obtain a model of direct teaching is of 6.08 ".

2. The results of the attitude (response) students obtained: (1) most $(88,62 \%)$ students interested in the lessons of mathematics, (2) the Majority (95\%) of students earnestly following the lessons of mathematics, (3) the Majority (88\%) students love learning model Problem Based Instruction, (4) Most $(93,21 \%)$ students stated that the learning model Problem Based Instruction is beneficial; (5) Most (88,92\%) students like on the Student worksheet (LKS), Based on these data, the response of the students positively to the learning Problem Based Instruction.

\section{REFERENCES}

Abbas, N. dkk. 2006. Meningkatkan Hasil Belajar Matematika Siswa Melalui Model Pembelajaran Berbasis Masalah Dengan Penilaian Portofolio Di SMPN 10 Gorontalo. (Online). (http;//www.depdiknas.go.id/jurnal/S1/nurhayati-penerapan.pdf, 10 Oktober 2009).

Agung, IGN. 1992. Metode Penelitian Sosial (Pengertian dan Pemakaian Praktis). Bagian I. Jakarta: Gramedia.

Arends, I.R. 2008. Learning To Teach Belajar Untuk Mengajar Buku Satu. Yogyakarta: Pustaka Pelajar.

2008. Learning To Teach Belajar Untuk Mengajar Buku Dua. Yogyakarta: Pustaka Pelajar.

Arikunto, S. 2002. Dasar-Dasar Evaluasi Pendidikan. Jakarta: Bumi Aksara

Atun, I. 2006. Pembelajaran Matematika Dengan Strategi Koopretaif Tipe Student Teams Achievement Divisions Untuk Meningkatkan Kemampuan Pemecahan Masalah dan Komunikasi Siswa. Tesis tidak diterbitkan. Bandung: Program Pascasarjana UPI Bandung.

Barrows, S.H. 2003. Problem Based Instruction (PBI). (Online). (http://web.cortland.edu/frieda/ID/IDtheories/46.html, diakses 10 Oktober 2009).

Ben-Zeev, T, \& Sternberg, R.J. 1996. The Nature of Mathematical Thinking. Mahwah. NJ: Lawrence Erlbaum Associates,Inc. 
Dahar, R.W. 1989. Teori-Teori Belajar. Jakarta: Erlangga.

Depdikbud. 1995. Garis-garis Besar Program Pengajaran (GBPP) Mata Pelajaran Matematika. Jakarta: Depdikbud.

Dorhayani, S. 2009. Keefektifan Pembelajaran Matematika dengan Pendekatan Kontekstual pada Siswa Kelas VIII SMP Negeri-2 Rantau Selatan Rantauprapat. Tesis tidak diterbitkan. Medan: Program Pascasarjana Universitas Negeri Medan.

Dunn, O.J. 1974. Applied Statistic Analysis of Variances and Regression. New York: John Wiley \& Sons, Inc.

Kantowski, M.G.1981. "Problem Solving”. Mathematics Education Research: Implications for the 80.. Virginia: NCTM.

Karno, T. 1996. Mengenal Analisis Tes (Pengantar ke Program Komputer ANATES). Bandung: Jurusan Psikologi dan Bimbingan FIP IKIP.

Kemp, J.E. 1994. Designing Effective Instruction. New York : Macmilan Colege Publishing Company.

Kusaeri, 2006. Profil Kemampuan Dasar Mahasiswa Jurusan Tadris Pendidikan Matematika Fakultas Tarbiyah. (Online). (http://ejournal.sunanampel.ac.id/index.php/Qualita/article/viewFile/133/121, diakses 10 Oktober 2009).

Marzuki, A. 2006. Implementasi Pembelajaran Kooperatif (Cooperatif Learning) Dalam Upaya Meningkatkan Kemampuan Koneksi dan Pemecahan Masalah Matematik Siswa. Tesis tidak diterbitkan. Bandung: Program Pascasarjana UPI Bandung.

Meyers, M.E. 2007. What is Activity Theory?. (Online). (http://www.britannica.com/bps/additionalcontent/18/25607288, diakses 20 Juli 2010).

Morrison, F.D. 1983. Applied Analysis Statistical Methods. New Jersey: Prentice-Hall, Inc.

Muin. 2005. Pendekatan Metakognitif Untuk Meningkatkan Seluruh Aspek Kemampuan Matematika. Tesis tidak diterbitkan. Bandung: Program Pascasarjana UPI Bandung.

NCTM. 2000. Defining Problem Solving. (Online). (http://www.learner.org/channel/courses/teachingmath/gradesk 2/session 03/sectio 0 3 a.html, diakses 10 September 2009).

Netter, J. 1974. Applied Linier Statistical Model. Illions:

Richard D. Erwin, INC. 
Noer, S.H. 2007. Pembelajaran Open-Ended Untuk Meningkatkan Kemampuan Pemecahan Masalah Matematik dan Berpikir Kreatif. . Tesis tidak diterbitkan. Bandung: Program Pascasarjana UPI Bandung.

Nurhadi, dkk. 2003. Pembelajaran Kontekstual dan Penerapannya Dalam KBK. Malang: Universitas Negeri Malang. 